\title{
EXPLORING THE WORLD'S LARGEST ERP IMPLEMENTATION: THE ROLE OF ERP IN STRATEGIC ALIGNMENT
}

\author{
D. Lance Revenaugh, Montana Tech University, Colorado Technical University, Irevenaugh@mtech.edu \\ TylerS.Cook, Montana Tech University, tscook@mtech.edu
}

\begin{abstract}
As one of the largest and most complex organizations in the world, the Department of Defense (DoD) faces many challenges in solving its well-documented financial and related business operations and system problems. The DoD is in the process of implementing modern multifunction enterprise resource planning (ERP) systems to replace many of its outdated legacy systems. This paper explores the ERP implementations of the DoD and seeks to determine the impact of the ERP implementations on the alignment of the DoD's business and IT strategy. A brief overview of the alignment literature and background on ERP are followed by case study analysis of the DoD ERP development and current implementation status. Lastly, the paper explores the current successes and failures of the ERP implementation and the impact on the DoD's goal of strategic alignment.
\end{abstract}

KEYWORDS: Enterprise Systems, ERP Implementation, Strategic alignment, Change management, Department of Defense

\section{INTRODUCTION}

The Department of Defense (DoD) is one of the largest and most complex organizations in the world. It faces many challenges in solving its well-documented financial and related business operations and system problems. The DoD is currently in the process of implementing modern multifunction enterprise resource planning (ERP) systems to replace many of its legacy systems. The principle driver for this effort is the Congressional requirement that the DoD have auditable financial statements by fiscal year 2017. The DoD has never had financially auditable statements.

In addition the auditability objective, the other expressed goals of the DoD ERP effort are to 1) reengineer its business and system processes resulting in, 2) better alignment between its Business and IT strategies. In order to research what the DoD is doing related these goals, we must first understand what is meant by strategic alignment and also what an ERP is and is not.

\section{IT And Business Strategic Alignment}

The Strategic Alignment Model (SAM) of Henderson and Venkatraman [25] continues to be widely used as the basis of Business/IT Alignment theories. The model is shown in figure 1 though the details of the model will not be explained here. See Papp 2001 [50] for a clear and comprehensive explanation of the model. The key message of this model, as well as that of many other studies, is that to become a successful company, one should make sure that the IT strategy is fully aligned with business strategy.

SAM and other alignment models continue to be developed and updated because traditional methods of developing business strategies have failed to take full advantage of technology. In the past, information technology (IT) was typically treated as a "cost center" or viewed as an "expense" rather than an enabler of business value. Strategic information systems shed new light on technology and its role in the development of business strategies. In today's increasingly "flat world" [17], it is no longer economically feasible to treat IT as a lower level support tool; failure to leverage IT may seriously hamper the firm's performance and viability in today's global, information-intensive world. Alternatively, by understanding and leveraging the Business/IT partnership, organizations can concentrate on the application of IT to enable the business strategy $[40,48]$. This harmony can be extended and applied throughout the organization as new opportunities are identified. 


\section{Business $\quad$ I/T}

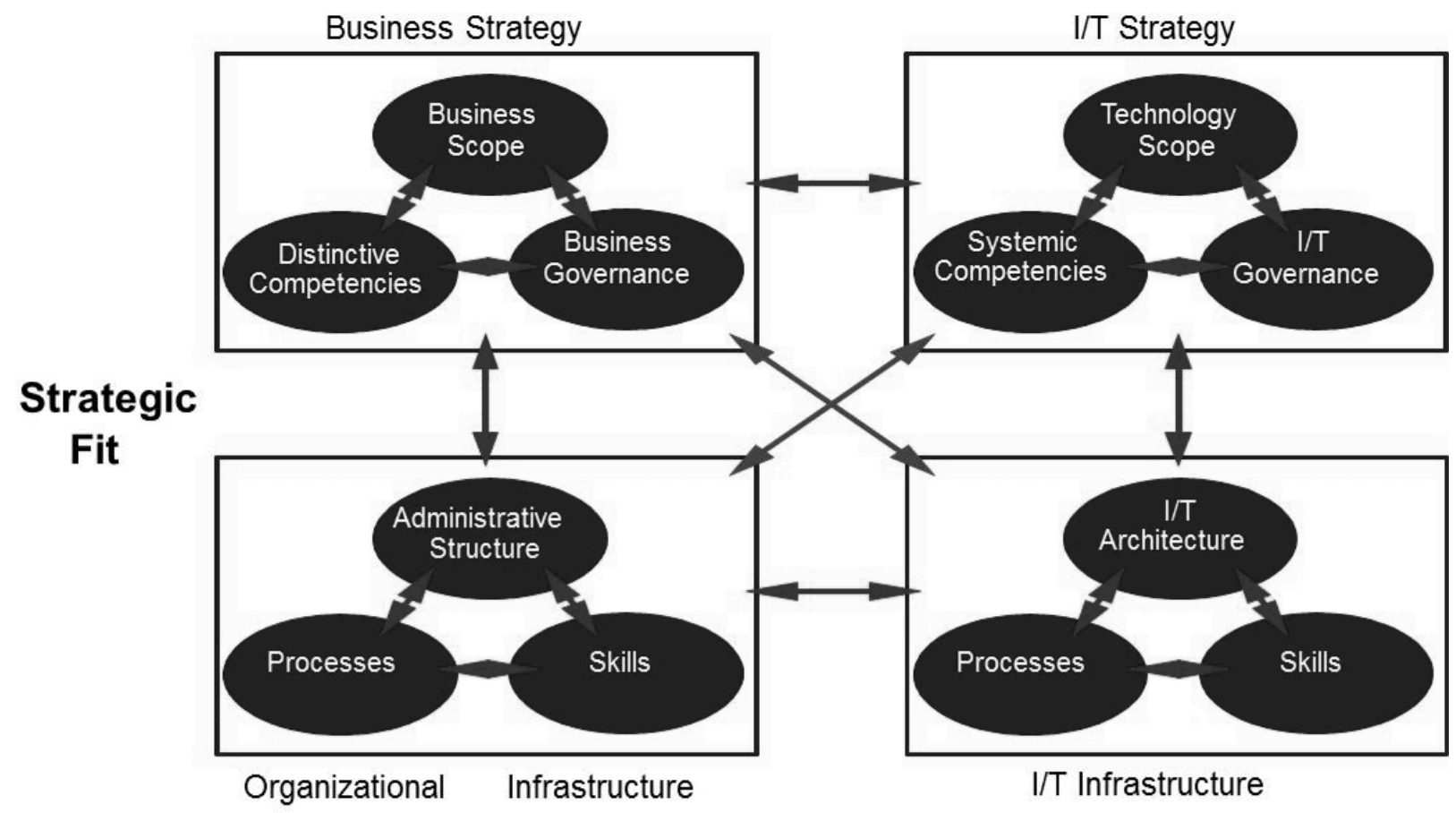

Functional Integration

Figure 1. Strategic Alignment Model [25]

Over the past several decades, extremely large sums of money have been invested in information systems and technology. Nevertheless, organizations seem to find it difficult or impossible to harness the power of information technology for their own long-term benefit, even though there is worldwide evidence $[12,13,42,53,34]$ that IT has the power to transform whole industries and markets. Strategic alignment, a method of applying IT in an appropriate and timely way, in harmony with business strategies, remains a key concern of business executives [34, $22,23,12,13,39,37,18,36]$. In fact, alignment's importance has been well known and documented for more than 30 years $[43,27,44,4,89,46,12,13]$. This classification has continued as indicated via its persistent top ranking in the business press by executives. Alignment seems to grow in importance as companies strive to link technology and business in light of dynamic business strategies and continuously evolving technologies [48]. Importance aside, what is not clear is how to achieve this harmony between business and IT, and what the impact of misalignment might be on the firm [48]. The ability to achieve and maintain this synergistic relationship is anything but easy. For years, firms have been channeling billions of dollars into technology in an attempt to successfully incorporate technology into their processes and long-term plans. Many of these efforts have failed despite overwhelming evidence of IT's ability to transform both individual firms and entire industries.

The alignment of information technology (IT) and business strategy to leverage the capabilities of IT and to transform the business has increased in importance as firms strive for competitive advantage in a diverse and changing marketplace $[15,1,5]$. In light of this, there has been a great deal of research and insight into the linkages between Business and IT [6, 37, 13, 24], the role of partnerships between IT and business management [31, 29], as well as the need to understand the transformation of business strategies resulting from the competitive use of IT [3]. Firms have been able to change not only their business scope, but also their infrastructure as a result of innovation regarding IT $[30,16]$. 
Simply put, aligning information technology with business strategy and plans means that a positive relationship between information technologies and the organization's accepted financial measures of performance exists [55]. In order to achieve alignment, an organization must first identify the sources of misalignment. Then, with the assistance of models discussed earlier in this paper, progress can be made toward a cohesive and consistent alignment of IT/IS strategy and the business strategy.

\section{Enterprise Resource Planning Systems}

An Enterprise Resource Planning (ERP) system is software designed to model and automate many of the basic processes of a company, from finance to the shop floor, with the goal of integrating information across the company and eliminating complex, expensive links between computer systems that were never meant to talk to each other [33, 14]. These systems offer online real-time information, which reduces processing time and frees managers and analysts from taking time to gather decision-making information.

ERP systems are becoming ubiquitous in the corporate world. They also continue to penetrate the small- and medium-sized company as firms like SAP and Oracle go after these large markets. Although the benefits of these systems are many, businesses today seem to be moving toward this technology primarily because the systems are considered to be a source of competitive advantage or at least a way to keep up with the competition. However, these systems bring with them their share of problems. Implementing these systems usually involves a significant amount of process change and often dictates changes in organizational structure. In fact, many ERP implementations are used as a means for re-engineering the firm. Management has a big role in the success and acceptance of these systems. As with the other technologies mentioned, the business process redesign inherent in ERP implementations requires major technical, organizational, and cultural change. The biggest associated challenge is fostering a new culture and managing the changes with consistency and coordination $[57,7]$.

When implementing information systems, there are usually two paths to take: adapting the inherent process to the people, or the people to the process. The former view stresses people as a firm's fundamental resource, while the latter view emphasizes consistency and coordination of corporate-wide information. Neither path has been proven better, however. More frequently today, these large ERP systems, which are designed around best practices, are being used as a facilitator of change in companies. This point is supported by Dwight Klappich, vice president of industry marketing at Ross Systems Inc of Atlanta: "The key thing when you look at the success or failure of software implementation is whether the client is implementing software or are they implementing change within their business [56].

In addition, client-server ERP systems feature many advantages over their mainframe counterparts. Most importantly, they can transfer data in real-time between locations worldwide. They can also support multiple currencies and multiple languages so they can be used at various global locations. The move to these systems has been fostered in a large part because they are industry standard compliant, giving many companies the ability to avoid the costly conversion processes of their legacy systems associated with these events.

\section{ERP Impact}

Recognizing the firm-wide impact of these systems, ERP market leader SAP started the trend of selling information systems to CEOs. Other technology companies are following this same strategy as they have also realized that IT is having a greater impact on strategic capabilities and the bottom line. This strategy also protects against two of the key components of failure for IT projects; namely, lack of congruence between a company's business strategy and its IT goals and lack of upper management support $[33,7]$.

The name of the game in today's business environment is speed and flexibility. Companies in every industry are constantly under pressure to perform their service or production faster and tailored to the needs of the customer. To accomplish this, companies need to streamline operations from the time an order is placed to its delivery. ERP enables this. 


\section{Issues in Information Systems}

Volume 14, Issue 1, pp.347-357, 2013

\section{ERP Problems}

ERP systems do present many problems for companies, however. The first has to do with the fact that they are usually part of a larger re-engineering effort. Therefore, the costs and time expectations of implementation are usually exceeded. Secondly, many companies purchase ERP systems to satisfy what they perceive will be a single integrated solution to all their data processing needs. ERP systems are not IT silver bullets. ERP systems are not good at everything and cannot perform all the processes that a firm may already have in place. This requires firms to either change processes or use additional applications, the idea of which runs counter to a single-solution philosophy.

\section{No ROI}

Early ERP implementation projects ran into the problem of not providing an easy means for determining the project's return on investment. Since the typical ERP implementation costs can be anywhere from $\$ 30$ to $\$ 100$ million, managers were very concerned with a means to measure their investment. However, today these projects are not being viewed as measurable purely by traditional financial analysis. Rather, intangibles are often being used to measure their success. Commenting on SAP, John Donovan, chairman of Cambridge Technology Group, says, "There is no return on these projects. Everyone is looking at this investment the wrong way and doing the wrong analysis, calculating the replacement of one system for another. SAP is the infrastructure. What is my return on putting electricity in this building? There is none; I just have to do it," [2]. Examples of some of the intangible measurement criteria being used include customer satisfaction, employee morale, and employee turnover. These factors are all difficult to link directly into an IT project and are difficult to measure. Revenue improvement goals are a commonly used financial target.

\section{METHODOLOGY}

Each DOD ERP system effort is extensive, as discussed in the next section. The purpose of this research is to glean understanding and insight from the current successes and failures of the ERP implementations. Rather than wait until they are all considered "completed," (which may never occur) and do a large systematic case study, this research seeks to explore the current status and evaluation of the DOD ERPs at whatever state of completion they are in (see Table 1 later in this paper) at this point in time. As such, a slightly unusual methodology of combining aspects of both descriptive and explanatory case study/analysis approaches has been applied.

\section{World's Largest ERP Project: US Department of Defense}

\section{DoD Financial Audit Mandate}

The Department of Defense (DoD) has recently undertaken the world's largest ERP effort in order to transform their operations through business systems modernization. This massive and costly undertaking is in response to the Financial Improvement and Audit Readiness (FIAR) plan which claims to be the DoD roadmap to fix internal controls, correct processes, and obtain an unqualified audit opinion (Inspector General, 2012). The plan is part of a larger effort intended to make the DoD's financial statements ready for audit by fiscal year (FY) 2017. Further, it calls on the respective military branches to modernize their business and financial systems environment, specifically, implementation of ERP systems and the retirement of legacy systems. In order to adequately address the impediments, the plan suggested the entities implementing the ERP systems should map known processes and control weaknesses to verify that the systems will adequately address the impediments [28]. The FIAR plan, however, does not specifically align ERP implementation with achieving audit readiness.

Figure 2 presents the Department of Defense Management Structure. According to the Inspector General Report (2012), The Deputy Chief Management Officer (DCMO) is the Principal Staff Assistant and advisor to the Secretary of Defense and Deputy Secretary of Defense for matters relating to the management and improvement of integrated DoD business operations. Further, the DCMO is responsible for aligning business operations of the DoD with the war fighting mission. Chief Management Officers (CMOs) of the military departments report to the DCMO issues they've identified in business operations within and among their respective departments [28]. Furthermore, each 
CMO is tasked with developing a comprehensive business transformation plan capable of providing accurate and timely information in support of business decisions of the military department [28]. Moreover, the determination of appropriate BPR efforts in order to align business processes with business system modernization (ERP implementation) is the responsibility of the DoD DCMO and the Military Department CMOs. Business process modernization, therefore, can be restructured or terminated altogether if BPR requirements are not satisfied.

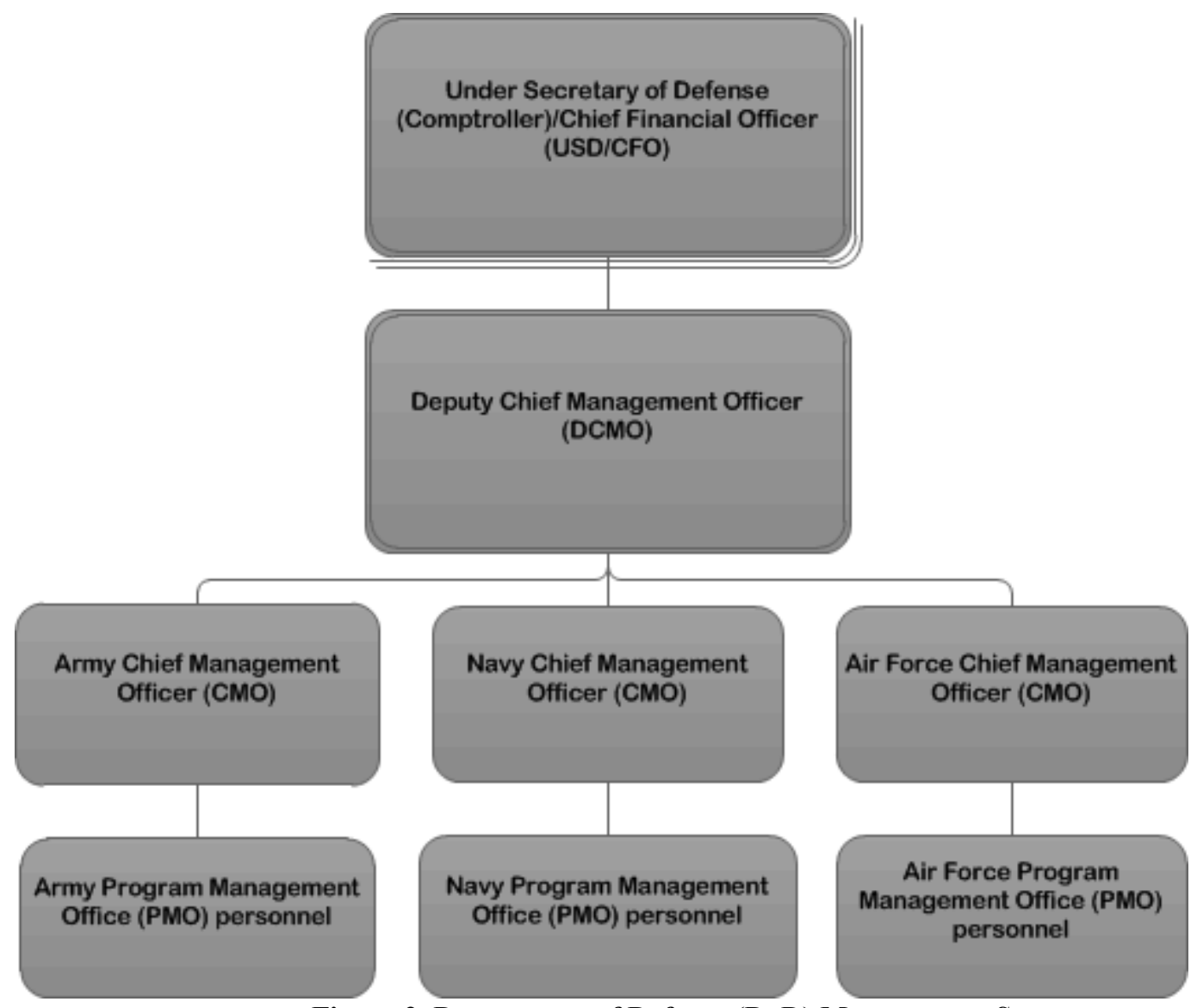

Figure 2. Department of Defense (DoD) Management Structure

In order to align the implementation of ERP systems with DoD's auditability goals, business process reengineering practices are critical to the success of the project. In addition, strong oversight is needed to identify the sources of misalignment. However, recent audit work by the DoD OIG and GAO has determined the DoD DCMO and the CMOs of the military departments did not verify that business processes were streamlined and efficient. Further, they did not review the business processes nor did they determine the reliability of the Program Management Office (PMO) submissions. According to the Inspector General Report [28], the PMOs did not properly reference the BPR assessment form which contained questions as to whether the business process maps generated by the PMOs identified how business system modernization will address identified inefficiencies.

\section{DoD ERP Systems}

As discussed in the previous section, the DoD was given a mandate to be "audit ready" by FY 2017. In order to accomplish this tremendous challenge, the DoD determined to undertake six ERP efforts as the major driver for meeting the mandate. The six ERP systems are shown in figure 3 and apply to the Navy, Army (GFEBS and LMP), Air Force (DEAMS), and DoD in general (EBS and DAI). 
While the details of what is included in each of the DoD ERP systems are beyond the scope of this paper, implementation efforts have been ongoing since 2003 (for details on each of the systems, see [32]). The original cost estimate for these systems is shown below in Table 1 and totals a little over $\$ 7$ billion. In addition, the table shows the planned number of users for each system, the current actual number of users, as well as the updated cost estimate for each system. The final column calculates the budget difference (projected final cost overrun) in millions of dollars. Projected cost overruns (as of Feb 2012) for each ERP is from \$56.8 million to \$3.94 billion.

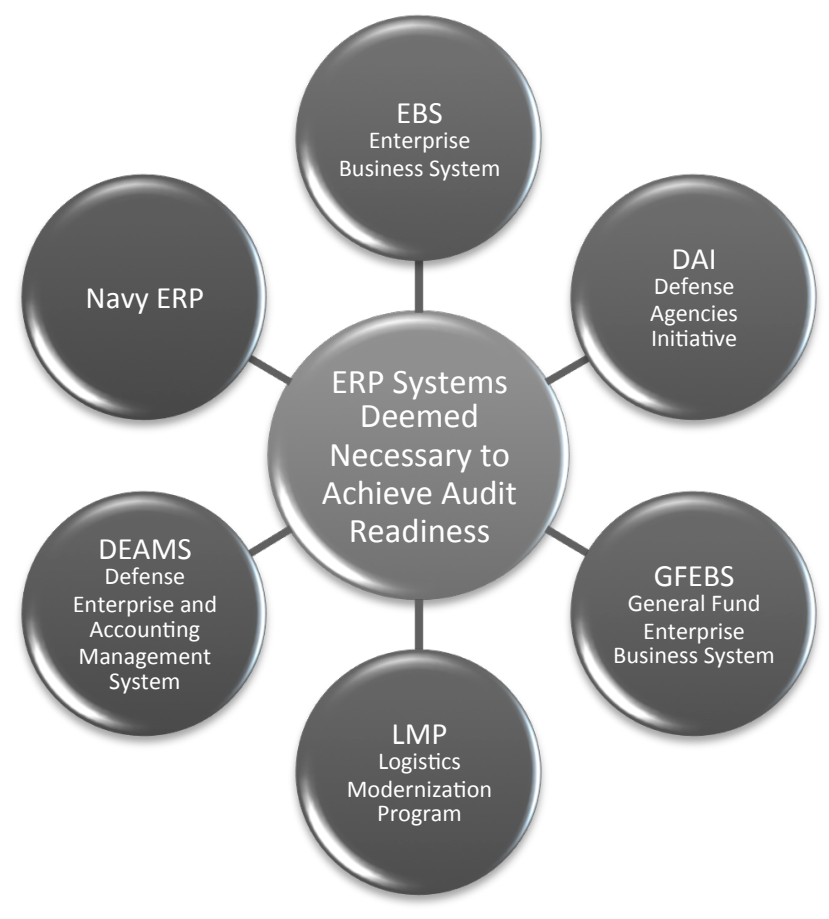

Figure 3. DoD ERP Systems 
Table 1. Status of Key DoD ERP Systems as of February 2012 [51]

\begin{tabular}{|c|c|c|c|c|c|c|c|}
\hline & $\begin{array}{l}\text { Initial } \\
\text { deploy- } \\
\text { ment } \\
\text { date }\end{array}$ & $\begin{array}{l}\text { Current } \\
\text { number } \\
\text { of users }\end{array}$ & $\begin{array}{l}\text { Planned } \\
\text { number } \\
\text { of users }\end{array}$ & $\begin{array}{c}\text { Current } \\
\text { users as } \\
\% \text { of } \\
\text { planned }\end{array}$ & $\begin{array}{l}\text { Original } \\
\text { life-cycle } \\
\text { cost } \\
\text { estimate } \\
\text { (millions) }\end{array}$ & $\begin{array}{l}\text { Current } \\
\text { life-cycle } \\
\text { cost } \\
\text { estimate } \\
\text { (millions) }\end{array}$ & $\begin{array}{l}\text { Difference } \\
\text { (millions) }\end{array}$ \\
\hline GFEBS & 2008 & 46,000 & 53,000 & $86.79 \%$ & $\$ 1,353.90$ & $\$ 1,425.30$ & $\$ 71.40$ \\
\hline LMP & 2003 & 21,000 & 21,000 & $100.00 \%$ & $\$ 420.00$ & $\$ 4,359.70$ & $\$ 3,939.70$ \\
\hline Navy ERP & 2007 & 40,000 & 66,000 & $60.61 \%$ & $1,632.90$ & $\$ 2,237.30$ & $\$ 604.40$ \\
\hline DEAMS & 2007 & 1,200 & 30,000 & $4.00 \%$ & $\$ 419.90$ & $\$ 2,158.90$ & $\$ 1,739.00$ \\
\hline DAI & 2008 & 8,000 & 94,000 & $8.51 \%$ & $\$ 209.20$ & $\$ 266$ & $\$ 56.80$ \\
\hline EBS-EC & 2011 & unknown & 700 & $n / a$ & $\$ 2,850.70$ & $\$ 4,026.50$ & $\$ \underset{*}{\$ 1,175.80}$ \\
\hline $\begin{array}{c}\text { EBS- } \\
\text { EProcurement }\end{array}$ & 2010 & 1,500 & 4,000 & $37.50 \%$ & $\$ 360.60$ & $\$ 774.40$ & $\$ 413.80$ \\
\hline
\end{tabular}

*includes cost of EBS Core, which supports ESB-EC and EBS-EProcurement. Source: DOD DODIG-2012-111 / Image:FierceGovernmentIT

Table 2 gives some additional detail as to when each system was to be fully deployed, when it is currently estimated to be fully deployed, and the difference between the two estimates. Data shows that the time delay for each ERP system ranges from 1.5 years to 12.5 years.

Table 2. Schedule Status of Key DoD ERP Systems as of May 2012 [28]

\begin{tabular}{|c|c|c|c|}
\hline System Name & $\begin{array}{l}\text { Original Full } \\
\text { Deployment }\end{array}$ & $\begin{array}{c}\text { Current } \\
\text { Full Deployment }\end{array}$ & Difference \\
\hline \multicolumn{4}{|l|}{ Army } \\
\hline GFEBS & December 2009 & July 2012 & 2.5 years \\
\hline LMP & June 2004 & September 2016 & 12.5 years \\
\hline \multicolumn{4}{|l|}{ Navy } \\
\hline Navy ERP & June 2011 & August 2013 & 2.0 years \\
\hline \multicolumn{4}{|l|}{ Air-Force } \\
\hline DEAMS & October 2009 & April 2017 & 7.5 years \\
\hline \multicolumn{4}{|l|}{ DoD } \\
\hline DAI & October 2011 & January 2016 & 4.5 years \\
\hline EBS-Core & October 2005 & July 2007 & 2.0 years \\
\hline EBS-EC & October 2012 & June 2014 & 1.5 years \\
\hline EBS-EProcurement & October 2011 & September 2013 & 2.0 years \\
\hline
\end{tabular}

\section{DoD ERP Implementation Evaluation}

Overall, the ERP implementations have not gone well $[32,51,9]$. As shown in Tables 1 and 2, the projects have been nearly $\$ 8$ billion over budget, delayed by an average of over four years, and currently servicing less than half of the intended users. An independent assessment of Defense Department ERP projects casts heavy doubts on the 


\section{Issues in Information Systems}

Volume 14, Issue 1, pp.347-357, 2013

likelihood of their eventual success. The report (see [52]) doesn't only question the execution of ERPs, it questions the ERP strategy itself. It recommends that the Pentagon curtail further deployment of the systems, pending a review of key elements including a "clear definition of the problem the ERP is attempting to solve" [52].

Among other things, the report points out that achieving auditability may also be a challenge because military services are counting on ERP implementation to force changes within their organizations, whereas an organization's willingness to change behavior and processes is a prerequisite for ERP success. This is a key point in the evaluation process; can an ERP force change or can it only be a major tool in supporting change?

In terms of top management support for the ERP effort, at the military service level, the only leaders with the authority and accountability to implement the necessary amount of change in an ERP implementation are the Secretary of Defense and the service chief and their immediate deputies. This level of leadership is required to initiate, facilitate and complete the ERP effort as well as manage the inevitable disagreements between parties. Moreover, the Secretary and the Service Chief would have to be personally engaged in the process since delegating authority has been shown not to work [52].

Failures, or "challenges," in the ongoing ERP implementations are spread across all branches of the DoD. For example, Khan [32] documents the following difficulties in attempting to achieve financial auditability (the primary goal of the ERP efforts):

- the Navy's and the Air Force's premature assertions of audit readiness and missed interim milestones;

- the Army's inability to locate and provide supporting documentation for its military pay;

- the Navy's and Marine Corps' inability to reconcile their Fund Balance with Treasury (FBWT) accounts;

- the Marine Corps' inability to receive an opinion on both its fiscal years 2010 and 2011 SBRs because it could not provide supporting documentation in a timely manner, and support for transactions was missing or incomplete.

On the other hand, there are reasons for the DoD to remain optimistic about business system modernization. One of DoD's highest-profile ERPs, the Army's General Fund Enterprise Business System (GFEBS), has been fully fielded across the Army. In an interview with FCW, Kristyn Jones, GFEBS director of financial information management, said, "We're on a good path to meet the goals. The Army is the only one of the services that has deployed their new financial system across the entire service, so that's a big step for us" [9].

\section{Impact of DOD ERP On Strategic Alignment}

According to Strassman [55], "All project plans are subject to change. Approval of a proposed investment is only the starting point for a continually widening gap between the stated objective and the capacity to deliver results." The success of the Army in implementing GFEBS is a perfect example of how to deliver results while remaining flexible. Further, the Army's approach has been incremental - rolling out GFEBS in "waves" and sharing best practices along the way. Kristyn Jones expanded on the process, saying, "We've used a crawl-walk-run approach...It's made each follow-on wave easier. We also engage with other offices a lot. It's been useful, as the services rolling out their [separate] systems, to talk to each other, sharing lessons learned and capabilities" [9]. Moreover, the Army recognizes that alignment between business system modernization and the stated objectives must remain updated as the organization evolves.

Ultimately, alignment must not take place through IT push, but through operational pull [55]. According to the Institute for Defense Analyses (2011) report, military services are counting on their ERP implementations to force changes within their organizations. The institute asserts, however, that the organization's willingness to change behavior and processes must already be established prior to an ERP implementation if it is to be successful. Of all the DoD ERP projects, the Army's "crawl-walk-run" approach most effectively addressed the establishment of a willingness to change. By implementing GFEBS in this manner, the Army is able to demand what, how, and when IT shall deliver results. While the Army has been relatively successful in implementing GFEBS, it remains to be seen whether DoD's ERP initiatives will have the desired effect of achieving audit readiness. 


\section{Issues in Information Systems}

Volume 14, Issue 1, pp.347-357, 2013

"Before one tries to prescribe solutions to problems, one must necessarily understand and interpret the problems correctly" [55]. There are obvious, and likely some avoidable, difficulties that have arisen because of the failure to identify the sources of misalignment. The DCMO and CMOs are indirectly responsible for many of the issues and schedule delays that have occurred. Business system modernization efforts, although, have not been in vain and the prescription for success, in part, can be found in the Army's "crawl-walk-run" approach. Those reporting entities responsible for implementing the remaining five ERPs should take a standards-based approach similar to that of the Army's GFEBS.

\section{CONCLUSIONS}

Aligning information technology with business strategy means that a positive relationship between information technologies and the organization's accepted financial measures of performance exists. It is undoubtedly difficult to achieve and maintain a synergistic relationship between the two strategies. It is particularly so in DoD's case, given this is the world's largest implementation of ERP systems to date in terms of cost, scope, and complexity. However, the recognition on the part of the DoD that sustainability hinges on synchronizing radical technological and process changes is significant in any organizational setting; this critical realization, plus the successful prospects exemplified by the Army's implementation of GFEBS, warrant optimism for the future.

The question remains whether DoD's stated objective of achieving audit readiness is an appropriate foundation for the implementation of ERPs. In terms of alignment, DoD should be careful not to confuse audit readiness goals with the sustainability and efficiency by which the military may be capable of operating as a result of ERP implementation. The DoD has proven to be an excellent testing ground for assessing whether an ERP can drive change and a stronger strategic alignment.

\section{REFERENCES}

1. Adcock, K., Helms, M., \& Wen-Jang, K. (1993). "Information Technology: Can it provide a sustainable competitive advantage?" Information Strategy: The Executive's Journal, (Spring), 10-15.

2. Baatz, E.B. "Marketing Genius," CIO magazine web page, June 15, 1996. <www.cio.com/forums/061596_sap_sidebar.html> June 27, 1998.

3. Boynton, A., Victor, B., \& Pine II, B. (1996). Aligning IT With New Competitive Strategies, Competing in the Information Age, Luftman, New York, Oxford University Press.

4. Brancheau, J., \& Wetherbe, J. (1987). "Issues in Information Systems Management," MIS Quarterly, 11(1), 23-45.

5. Cardinali, R. (1992). "Information Systems--A Key Ingredient To Achieving Organizational Competitive Strategy," Computers in Industry, 18, 241-45.

6. Chan, Y., \& Huff, S. (1993). "Strategic Information Systems Alignment,” Business Quarterly, 58(1), 51-56.

7. Cliffe, Sarah. "ERP Implementation," Harvard Business Review, Jan/Feb 1999, Vol. 77, No. 1.

8. Conrad, K. (1994). Measure the strategic value of information technology investments. The Sagebrush Group. Retrieved from http://sagebrushgroup.com/archive19940823

9. Corrin, A. (2012). DoD officials cautiously tout progress in financial management reform. The Business of Federal Technology. Retrieved from http://fcw.com/Articles/2012/09/17/DoD-auditability-financialreform-ERP-GFEBS.aspx?Page=1

10. Davenport, T., \& Short, J. (1990). "The New Industrial Engineering: Information Technology and Business Process Redesign," Sloan Management Review, 11-27.

11. Dixon, P., \& John, D. (1989). "Technology Issues Facing Corporate Management in the 1990s," MIS Quarterly, 13(3), 247-55.

12. Earl, Michael J (1983). Corporate Information Systems Management, Homewood, Illinois, Richard D. Irwin, Inc.

13. Earl, Michael J (1993). "Experience in Strategic Information Systems Planning,” MIS Quarterly, 17(1), 1-24.

14. "ERP/Supply Chain Research" (1999). CIO magazine web page. <www.cio.com/forums/erp> (January 5, 1999).

15. Faltermayer, E. (1994). “Competitiveness: How US Companies Stack Up Now," Fortune, 129(8), (April 18), 52-64. 


\section{Issues in Information Systems}

Volume 14, Issue 1, pp.347-357, 2013

16. Foster, R. (1986). Innovation: The Attacker's Advantage, New York: Summit Books.

17. Friedman, T. (2006). The World Is Flat: A Brief History of the Twenty-first Century. Farrar, Straus and Giroux, 2006.

18. Goff, L. (1993). "You Say Tomayto, I Say Tomahto," Computerworld, (Nov. 1), 129.

19. GPRA. (1993). Government Performance and Results Act of 1993. Public Law, 103-62.

20. Hammer, M., \& Champy, J. (1993). Reengineering the Corporation: A Manifesto For Business Revolution, New York: Harper Business.

21. Hammer, M., \& Stanton, S. (1995). The Reengineering Revolution, New York: Harper Business.

22. Henderson, J., \& Venkatraman, N. (1990). "Strategic Alignment: A model For Organizational Transformation via Information Technology,” Working Paper 3223-90, Sloan School of Management, Massachusetts Institute of Technology.

23. Henderson, J., \& Venkatraman, N. (1996). "Aligning Business and IT Strategies," Competing in the Information Age, Luftman, New York, Oxford University Press.

24. Henderson, J., Thomas, J., \& Venkatraman, N. (1992). "Making Sense Of IT: Strategic Alignment and Organizational Context," Working Paper 3475-92 BPS, Sloan School of Management, Massachusetts Institute of Technology.

25. Henderson, J. C. \& Venkatraman, N. (1999). Strategic alignment: Leveraging information technology for transforming organizations. IBM Systems Journal, 38, 472-484.

26. Hsieh, C., Lin, B., \& Manduca, B. (2007). Information technology and six sigma implementation. Journal of Computer Information Systems, 1-10.

27. IBM (1981). Business Systems Planning, Planning Guide, GE20-0527, IBM Corporation, 1133 Westchester Ave, White Plains, New York.

28. Inspector General (2012). "Enterprise resource planning systems schedule delays and reengineering weaknesses increase risks to DoD's auditability goals," Department of Defense, July 13, 2012

29. Ives, B., Jarvenpaa, S., \& Mason, R. (1993). "Global Business Drivers: Aligning Information Technology to Global Business Strategy,” IBM Systems Journal, 32(1), 143-161.

30. Keen, P. (1991). Shaping the Future, Boston, MA: Harvard Business School Press.

31. Keen, P. (1996). "Do You Need An IT Strategy?" Competing in the Information Age, Luftman, New York, Oxford University Press.

32. Khan, Asif A; Melvin, Valerie; Barnes, Cindy B; Bird, Mark; Karls, Kristi; Holland, Michael; Yfantis, Chris ; Hattery , Maxine. (2012). "DoD Financial Management: Challenges in Attaining Audit Readiness and Improving Business Processes and Systems," United States Government Accountability Office, Testimony Before the Subcommittee on Readiness and Management Support, Committee on Armed Services, U.S. Senate, April 18, 2012.

33. Kimberling, Eric C. (2006). "Aligning ERP with Your Overall Business Strategy." Retrieved from http://it.toolbox.com/blogs/erp-roi/aligning-erp-with-your-overall-business-strategy-8747.

34. King, J. (1995) "Re-engineering Focus Slips," Computerworld, (March 13), 6.

35. Lacy, K. (2003). "Business/IT Alignment Concerns - Ask the Expert," CIO Magazine, June 2003.

36. Liebs, S. (1992). "We're All in This Together," Information Week, (October 26), 8.

37. Luftman, J. (1996). Competing in the Information Age: Practical Applications of the Strategic Alignment Model, New York: Oxford University Press.

38. Luftman, J. (1997). "Align in the Sand," Computerworld Leadership Series, (February 17), 1-11.

39. Luftman, J., Lewis, P., \& Oldach, S. (1993). "Transforming the Enterprise: The Alignment of Business and Information Technology Strategies,” IBM Systems Journal, 32(1), 198-221.

40. Luftman, J., Papp, R., \& Brier, T. (1999). "Enablers and Inhibitors of Business-IT Alignment," Communications of the AIS, 1, Article 11, (March, 1999).

41. Luftman, J., Papp, R., \& Brier. T. (1995). "The Strategic Alignment Model: Assessment and Validation," Proceedings of the Information Technology Management Group of the Association of Management (AoM) 13th Annual International Conference, Vancouver, British Columbia, Canada, August 2-5, 1995, 57-66.

42. Martin, E. (1983). "Information Needs of Top MIS Managers," MIS Quarterly, 7, (3) 1-11.

43. McLean, E., \& Soden, J., (1977). Strategic Planning for MIS, New York, John Wiley \& Sons,

44. Mills, P., (1986), Managing Service Industries, New York Ballinger. 
45. Newlin, J.S. (2009). Minimizing the human capital aspect of productivity disruption during implementation of an enterprise resource planning (ERP) system. Air Force Institute of Technology.

46. Niederman, F., Brancheau, J., \& Wetherbe, J. (1991). "Information Systems Management Issues For the 1990s," MIS Quarterly, 15(4), 475-95.

47. Orizon. Retrieved from http://www.orizon-inc.com/clients-success-stories-dod.aspx

48. Papp, R. (1995). Determinants of Strategically Aligned Organizations: A Multi-industry, Multi-perspective Analysis, (Dissertation), Stevens Institute of Technology, Hoboken, New Jersey.

49. Papp, R. (1998). "Alignment of Business and Information Technology Strategy: How and Why," Information Management, 11, \#3/4).

50. Papp, R. (2001). Strategic Information Technology: Opportunities for Competitive Advantage, Idea Group Publishing, 2001.

51. Perera, D. (2012). Key DoD ERPs $\$ 8$ billion over budget, say auditors. Fierce Government IT. Retrieved from http://www.fiercegovernmentit.com/story/key-dod-erps-8-billion-over-budget-say-auditors/201207-18

52. Perera, D. (2012). Systemic problems with DoD ERP strategy and implementation, warns report. Fierce Government IT. Retrieved from http://www.fiercegovernmentit.com/story/systemic-problems-dod-erpstrategy-and-implementation-warns-report/2012-09-23

53. Robson, W. (1994). Strategic Management and Information Systems: An Integrated Approach, London,, Pitman Publishing.

54. Rockart, J., \& Short, J. (1989). “IT in the 1990's: Managing Organizational Interdependence,” Sloan Management Review, 30(2), 7-17.

55. Strassman, P.A. (1998). What is alignment? Cutter IT Journal. Retrieved from http://www.strassman.com/pubs/alignment/

56. Trommer, Diane. "SCOR sets supply chain standard," TechWeb News, Sept. 29, 1997.

57. Wen-Hsien, Tsai; Elliott, T.Y. Hwang; Jui-Chu, Chang; Chien-Wen, Lai; Sin-Jin, Lin. (2012) "Turning around troubled projects in an ERP implementation project from consultancy project leaders' perspectives," International Journal of Business and Systems Research, 6(2),123-149. 